\title{
A Simplified Analytical Procedure for Simultaneous Determination of Alkylphenol Ethoxylates and Brominated Flame Retardants in Fish Tissue Samples from Vaal River, South Africa
}

\author{
Tlou B. Chokwe ${ }^{1}$, Jonathan 0. Okonkwo ${ }^{2 *}$, Linda L. Sibali ${ }^{3}$, Elmari Krùger ${ }^{1}$, Hein du Preez ${ }^{1}$, \\ Reveck Hariram ${ }^{1}$, Esper J. Ncube ${ }^{1}$ \\ ${ }^{1}$ Scientific Services, Rand Water, Vereeniging, South Africa \\ ${ }^{2}$ Department of Environmental, Water and Earth Sciences, Tshwane University of Technology, Pretoria, South \\ Africa \\ ${ }^{3}$ Directorate of Research and Innovation, Tshwane University of Technology, Pretoria, South Africa \\ Email: ${ }^{*}$ OkonkwoOJ@tut.ac.za
}

Received 2 March 2015; accepted 31 March 2015; published 2 April 2015

Copyright (C) 2015 by authors and Scientific Research Publishing Inc.

This work is licensed under the Creative Commons Attribution International License (CC BY).

http://creativecommons.org/licenses/by/4.0/

(c) (i) Open Access

\begin{abstract}
In this study, the concentration of alkylphenol ethoxylates (APEs) and brominated flame retardants (BFRs) were determined in fish samples, Labeo umbratus and Carp, collected from the Vaal River in South Africa. Ultrasonic-assisted extraction technique was used to extract the organic contaminants from fish samples, and the resulting extract was purified by sulphuric acid lipid removal followed by Strata X-cartridge SPE clean-up. The APEs and BFRs were derivatized using heptafluorobutyric anhydride before analysis with GC-MS. In both types of fish samples, lower oligomers of APEs were more abundant than the higher oligomers, while HBCD, BDE99 and PBB101 were the dominant BFRs. The concentrations of these pollutants ranged from $1.061 \mathrm{ng} / \mathrm{g}$ lipids ( $t$-BP) in Labeo umbratus to $11.860 \mathrm{ng} / \mathrm{g}$ lipids (HBCD) in Carp.
\end{abstract}

\section{Keywords}

Alkylphenol Ethoxylates, Brominated Flame Retardants, Fish Sample, Heptafluorobutyric Anhydride Derivatization, Vaal River, South Africa

\footnotetext{
"Corresponding author.

How to cite this paper: Chokwe, T.B., Okonkwo, J.O., Sibali, L.L., Krùger, E., du Preez, H., Hariram, R. and Ncube, E.J. (2015) A Simplified Analytical Procedure for Simultaneous Determination of Alkylphenol Ethoxylates and Brominated Flame Retardants in Fish Tissue Samples from Vaal River, South Africa. American Journal of Analytical Chemistry, 6, 422-428. http://dx.doi.org/10.4236/ajac.2015.65041
} 


\section{Introduction}

Due to high levels of industrial activities in most big cities, the pollution of aquatic systems is generally higher in cities than in rural environment. This is due, in part, to sewage systems receiving effluents from many industrial processes along with domestic wastewater. Such wastewaters, most often, tend to contain a wide range of toxic organic and inorganic substances [1]. Among the chemicals potentially associated with urban wastewater, alkylphenol ethoxylates (APEs) and brominated flame retardants (BFRs) have been identified as one of the nuisance toxic groups. Their presence in aquatic environmental is as a result of their use in several consumer and personal-care products and as flame retardants in electrical and electronic appliances. These organic pollutants, as well as their degradation by-products, are known to be persistent, bio-accumulating and highly toxic, with potential for estrogenic activity [2] [3].

Alkylphenol ethoxylates are one of the most widely used surfactants. They have been used in domestic detergents, pesticide formulations and industrial products [4]. These compounds find their way into the environment in their original form and as natural degradation products of the parent alkylphenol ethoxylates that are popularly used in commerce for their surfactant properties [5]. The levels of these APEs metabolites present in the environment may be well above the threshold necessary to induce endocrine disruption in wildlife. These findings have raised public concern over their environment and human health effects [4]. Brominated flame retardants have shown to be the most effective in the inhibition of fires and are material of choice because of their low cost and lower loading of substrate [6]. Of all the BFRs, PBDEs are the most commonly used compared with polybrominated biphenyls (PBBs), hexabromocyclododecane (HBCD) and tetrabromobisphenol (TBBPA) [2]. Different PBDEs congeners such as decabrominated diphenyl ether (BDE209), are known to be photo-chemically degraded by ultraviolet light resulting in the formation of less brominated PBDEs that are more persistent, bioaccumulative and toxic [7].

Humans can be exposed to these compounds through different sources such as consumption of contaminated foods, inhalation of contaminated particles or direct contact with materials that have been treated with APEs and BFs [8] [9]. Other sources of human exposure included water supply and sewage sludge used as fertilizers. Several studies have confirmed the presence of these pollutants in fish [5] [8]-[13]. So far, the information on the levels of these pollutants in fish samples from around Africa including South Africa is still scarce. Studies conducted to date in some South African environmental samples (waters and sediments) have shown the presence of organochlorinated [14], alkylphenol ethoxylates [15] and PBDEs [16] [17]. With the exception of recent study by Polder et al. [18] who reported the presence of HBCD in bird egg in South Africa, the authors are not aware of any report on the simultaneous determination of APEs and BFRs in fish samples. This study describes a simplified method for the simultaneous quantification of alkylphenol ethoxylates and brominated flame retardants in fish matrices using ultrasonic extraction followed by concentrated sulphuric acid fats removal and solid phase extraction clean-up; heptafluorobutyric anhydride derivatization and gas chromatography-mass spectrometry determination.

\section{Materials and Methods}

\subsection{Materials}

\subsubsection{Standards and Reagents}

Derivatizing agents (heptafluorobutyric anhydride (HFBA)) was of analytical grade purchased from Sigma-Aldrich, South Africa. The solvents, acetone and hexane used in the study were of GC grade and were used without further purification. The APEs and PBBs were purchased from Laboratories Dr Ehrenstorfer-Schäfers, Augsburg, Germany. Only the NPE, NPPE and OPPE were of technical grade and the remaining APEs, PBBs and PBDEs were of analytical grade. Tetrabromobisphenol A of technical grade as Firemaster BP4A and hexabromocyclododecane of technical grade were purchased from AccuStandard, USA. Helium as He 5.5 pure was purchased from Air Product South Africa, Vereeniging.

\subsubsection{Fish Sample Collection}

Seven bottom feeders, Labeo umbratus, and nine predatory fish, Carp, were collected from the Vaal River. The selected fishes were caught using a fishing rod. Fish selected for analysis were killed by a blow to the head and were identified as males. The length and weight of each fish was recorded. The fish were individually wrapped 
in aluminum foil, placed in plastic bags packed with ice for transport to the laboratory where the samples were frozen pending preparation of the tissue samples. Fish tissue samples were prepared following the guidance in EPA [19]. Techniques to minimize potential for sample contamination were used. During sample preparation, non-talc nitrile gloves were worn and heavy-duty aluminum foil cutting board was used. The gloves and foil were changed between samples and the cutting board cleaned between samples. The fish were thawed enough to remove the foil wrapper and rinsed with tap water, then deionized water to remove any adhering debris. Before use, the skins were removed and the sample, muscle tissues, collected.

\subsection{Methods}

\subsubsection{Muscle Tissue Sample Preparation: Homogenization, Extraction and Clean-Up}

About $5 \mathrm{~g}$ of the tissue was weighed and mixed with $20 \mathrm{~g}$ anhydrous sodium sulphate and grounded to free flowing. The contents were extracted with $20 \mathrm{ml}$ of hexane/acetone mixture $(4: 1)$ at $55^{\circ} \mathrm{C}$ for $45 \mathrm{~min}$ in two cycles. After the ultrasonic extraction, the extracts were combined and placed in separating funnel. Roughly 10 $\mathrm{ml}$ of concentrated sulphuric acid was added, the mixture shaken for $5 \mathrm{~min}$ and phase separated. The acid layer was washed once with $25 \mathrm{ml}$ of hexane. The hexane extracts were combined and washed with $40 \%(\mathrm{v} / \mathrm{v})$ sulphuric acid for further removal of residual lipids. The phases were separated and the organic phase evaporated to dryness using TurboVap II instrument. The residue was re-constituted with $2.5 \mathrm{ml}$ of $\mathrm{MeOH}$, diluted to $250 \mathrm{ml}$ with MilliQ water and acidified to $\mathrm{pH} 3$ with acetic acid. The mixture was then passed through an SPE cartridge conditioned with $6 \mathrm{ml}$ of 30\% MeOH in DCM, followed by $6 \mathrm{ml}$ DCM. After passing the mixture through the cartridge, the cartridge was dried for $1 \mathrm{~h}$ and APEs and BFRs eluted with DCM:hexane (4:1) mixture. The eluates were then concentrated under a gentle stream of nitrogen to dryness and placed under derivatization conditions as described in our previous report [20]. Briefly, to the residue containing APEs and BFRs, $0.1 \mathrm{ml} \mathrm{hex-}$ ane; $70 \mu \mathrm{l}$ of $0.1 \mathrm{M}$ triethylamine (TEA) and $7 \mu \mathrm{l} \mathrm{HFBA}$ were added. The test tubes were closed and completely mixed for 1 min using a vortex system. The contents were gradually heated to $50^{\circ} \mathrm{C}$ and the derivatization was achieved within $30 \mathrm{~min}$. Thereafter, the contents were cooled, quenched with $0.3 \mathrm{~mL}$ of $5 \%$ aqueous solution of $\mathrm{K}_{2} \mathrm{CO}_{3}$. The organic phase was then drawn off. The aqueous phase was washed twice with $0.5 \mathrm{~mL}$ of hexane to recover some organic fractions. After separation, the organic phase extracts were concentrated to $100 \mu$. Thereafter, the internal standards (Chrysene and PBB80, $20 \mu \mathrm{l}$ of $2 \mathrm{ppm}$ each) were added into the extract, the volume made up to $200 \mu \mathrm{l}$ and $1 \mu \mathrm{l}$ of a mixture of extracts and internal standards injected into the GC-MS.

\subsubsection{Instrumentation and GC/MS Conditions}

An Agilent 6890 GC equipped with 5975 mass selective detector (MSD) was used for analysis. The GC was equipped with a Gerstel autosampler and separation performed on a capillary column (Restek RTx-1614, film thickness $0.10 \mu \mathrm{m}, 15 \mathrm{~m} \times 0.25 \mathrm{~mm}$ I.D. (Chromspec cc South Africa)). The GC/MS conditions used for analysis were as follows: carrier gas He; linear velocity, $40 \mathrm{~cm} \cdot \mathrm{s}^{-1}$; injector temperature, $275^{\circ} \mathrm{C}$; transfer line temperature, $280^{\circ} \mathrm{C}$; ion source $150^{\circ} \mathrm{C}$. For analysis $1 \mu \mathrm{l}$ splitless injection were carried out by autosampler. The GC temperature program conditions were as follows: initial temperature $50^{\circ} \mathrm{C}$, heated to $120^{\circ} \mathrm{C}$ by a temperature ramp of $7.5^{\circ} \mathrm{C} / \mathrm{min}$ then $275^{\circ} \mathrm{C}$ by a temperature ramp of $15^{\circ} \mathrm{C} / \mathrm{min}$ then finally heated to $280^{\circ} \mathrm{C}$ (held for $1 \mathrm{~min}$ ) by a temperature ramp of $25^{\circ} \mathrm{C} \cdot \mathrm{min}^{-1}$.

\subsubsection{Quality Assurance}

Several quality control measures were taken to ensure the correctness and integrity of the results. These include the use of pre-extracted tissue samples spiked with pure APEs and BFRs standard (16 ng/g and $80 \mathrm{ng} / \mathrm{g}$ ) to assess recovery. The recoveries ranged from $50.02 \pm 14.63$ (NPPE2) - $90.88 \pm 6.32$ (BDE47) with six values below $60 \%$. Several other quality assurance measures were also routinely observed in this study and included running blanks in between samples, analyzing samples in triplicates as well as analyzing test standard after every five samples.

\section{Results and Discussion}

A total of seven APEs isomers (tert-butylphenol (t-BP), tert-nonylphenol (t-NP), octylphenol ethoxylate (OPE), nonylphenol ethoxylate (mono-NPE), nonylphenol di-ethoxylates isomers (di-NPE1 and di-NPE2), octylphenol penta ethoxylates (OPPE), nonylphenol penta ethoxylates isomers (NPPE1 and NPPE2)); seven PBDEs congen- 
ers (BDE28, BDE47, BDE100, BDE99, BDE154, BDE153, BDE183) together with pentabromobiphenyl (PBB101) and hexabromocyclododecane (HBCD) were determined and quantified fish samples from the Vaal River, South Africa.

\section{Recovery Test}

Different methods were tested for lipid removal (2.92\% lipids, $n=9$, predatory; $2.44 \%, n=7$, bottom feeder) and recovery of APEs and BFRs from tissue samples. The following lipids removal methods, aminopropyl cartridge, destruction with concentrated sulphuric acid, silica gel stirring and/or their combinations were tested. With the aminopropyl cartridges, the lipids removal was $\sim 80 \%(n=4)$, while silica gel stirring gave a lipid removal of $65 \%(n=4)$. The combination of aminopropyl cartridge with silica gel column gave $98.3 \%$ lipid removal with recoveries of $10 \%-78.7 \%(n=5)$. This combination for lipid removal was found to be inadequate in removing lipids from the Carp species were $75 \%$ lipids removal was recorded. Concentrated sulphuric acid wash was used and $\sim 80 \%$ lipid was removed. However, by washing the post-extract with concentrated acid, followed by a dilute sulphuric acid $(40 \%(\mathrm{v} / \mathrm{v})), \sim 97 \%$ lipids $(\mathrm{n}=16)$ was removed and the recovery after lipids removal and SPE clean up ranged between $50.02 \pm 14.63$ (NPPE2) - $90.88 \pm 6.32$ (BDE47) as presented in Figure 1.

The developed method was applied to determine the concentration of sixteen (16) fish samples collected from the Vaal River. The composition of the fish were seven (7) bottom feeders, Labeo umbratus, and nine (9) predatory fish, Carp. The concentrations of APEs and BFRs from the samples are shown in Figure 2.

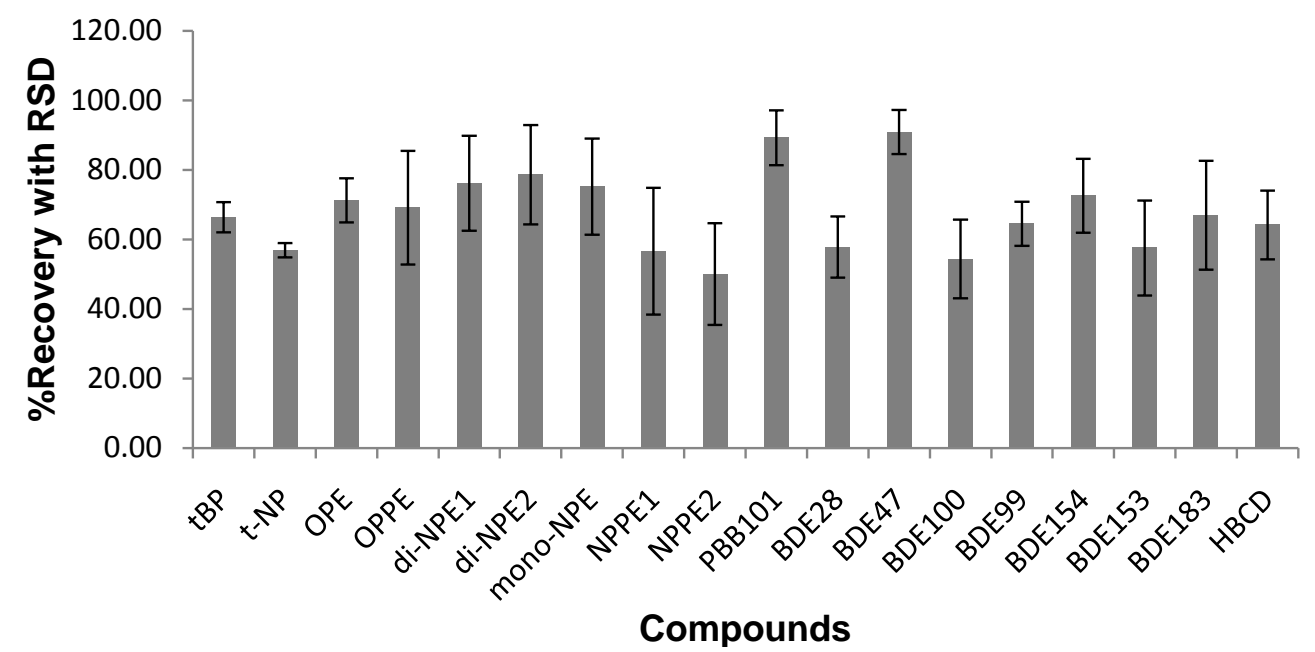

Figure 1. Recoveries of APEs and BFRs from tissue.

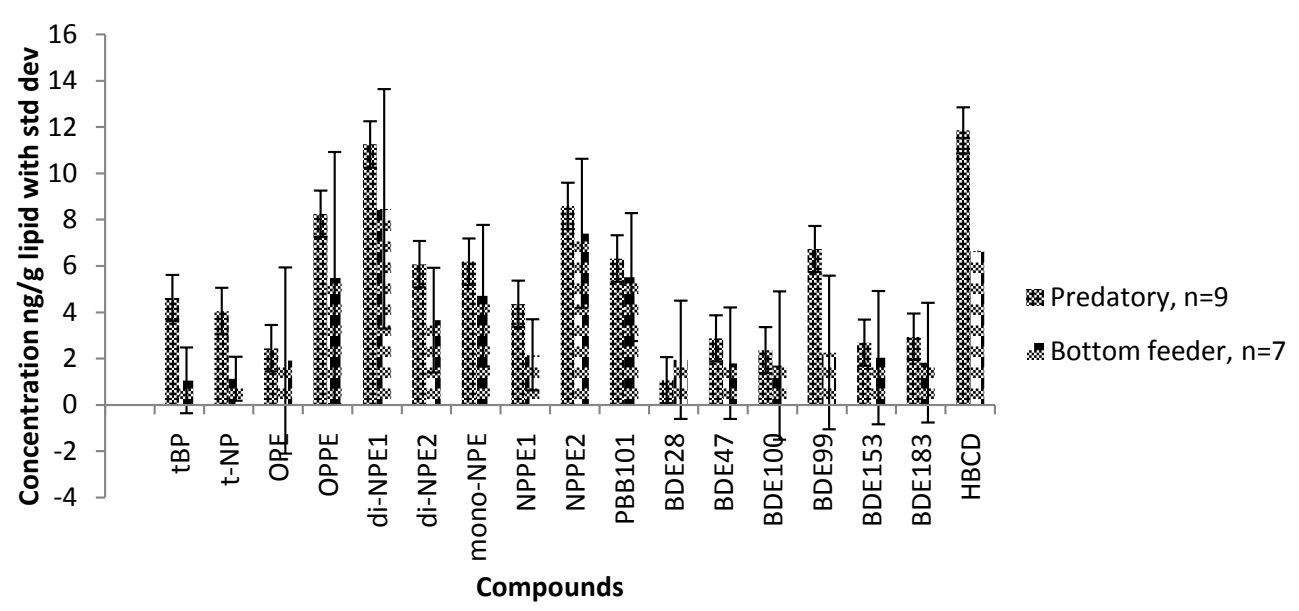

Figure 2. Levels of APEs and BFRs in fish samples from Vaal River. 
The concentrations of APEs from Carp fish followed the following pattern: di-NPE1 > OPPE/NPPE2 > diNPE2/mono-NPE $>t$-BP/t-NP/NPPE1 > OPE. The same pattern was also observed from Labeo umbratus. The BFRs concentrations pattern was as follows: HBCD > BDE99 > PBB101 > BDE47/BDE183 > BDE153/ BDE100 > BDE28 in both types of fish samples. It can also be observed in Figure 2 that higher concentrations of the organic contaminants were found in the predator than in the bottom feeder. The observed higher concentrations can be attributed to intake of already contaminated fish by the predator fish. The same pattern is observed in the sum concentrations of the analytes presented in Figure 3.

The results as presented in Figure 3 show that APEs are the major contaminants found in fish as compared to BFRs. With APEs, the lower ethoxy, i.e., di-NPE and mono-NPE, were found to be the most abundant at 23.52 ng/g lipids vs $12 \mathrm{ng} / \mathrm{g}$ lipids for NPPE with the remainder (10.6 ng/g lipids) being the sum of OPE and OPPE. These ratios were also observed by Schmitz-Afonso et al. [3], Rice et al. [5] and Datta et al. [8]. However, the concentrations obtained in this study were lower than the concentrations reported in those reports as shown in Table 1. With the BFRs, the PBB101 was detected in almost the same concentration in both fish while HBCD was slightly higher in Carp than in Labeo umbratus species. When compared to the results reported by Hiebl \& Vetter [21] as presented in Table 1, the concentration of HBCD was lower in this study. With the PBDEs, congener BDE99 was more abundant in Carp than in Labeo umbratus. This predominance of the penta congeners is

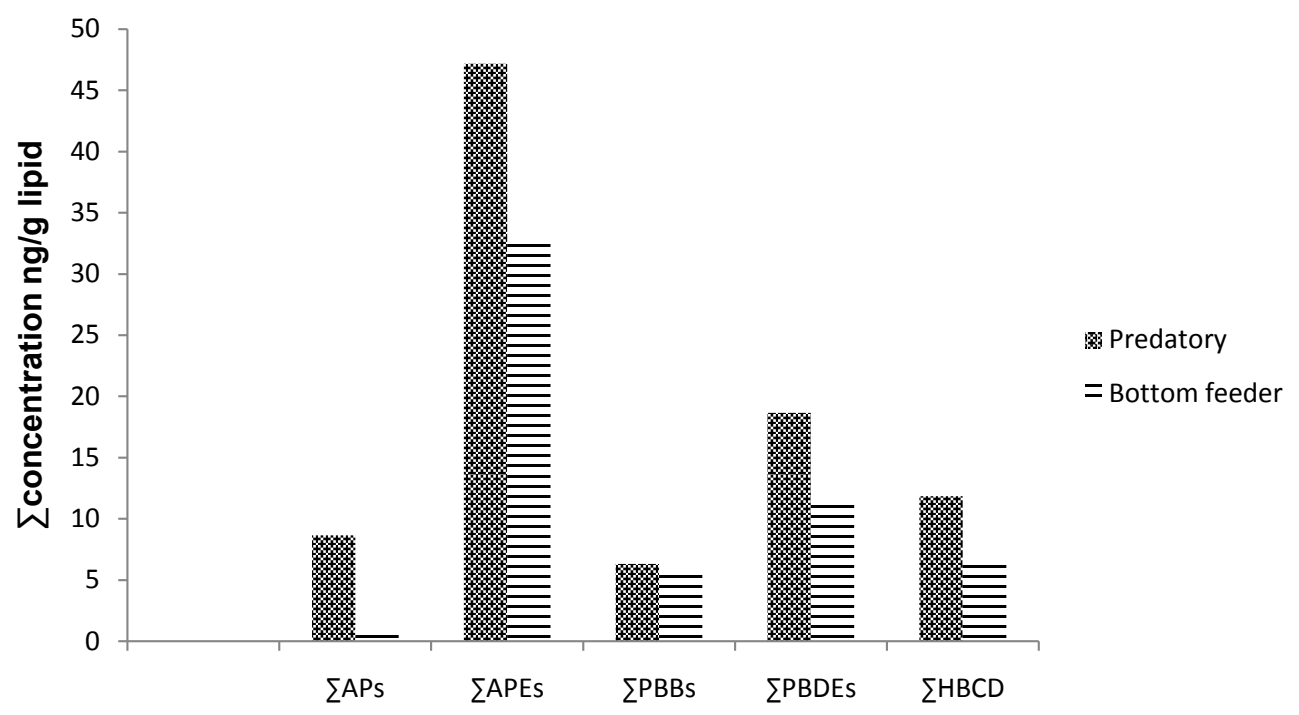

Figure 3. Sum concentration of APEs and BFRs in fish.

Table 1. Concentration of APEs and BFRs of fish samples from other studies (ng/g lipid).

\begin{tabular}{|c|c|c|c|c|c|c|}
\hline Area & Sample & $\sum$ PBDE & $\sum$ PBBs & $\sum \mathbf{A P E}$ & HBCD & Ref \\
\hline Canada & Mussel & $\mathrm{n} / \mathrm{a}$ & $\mathrm{n} / \mathrm{a}$ & $177-12,440$ & $\mathrm{n} / \mathrm{a}$ & {$[1]$} \\
\hline USA & Trout & $\mathrm{n} / \mathrm{a}$ & $\mathrm{n} / \mathrm{a}$ & $18-2075$ & $\mathrm{n} / \mathrm{a}$ & {$[8]$} \\
\hline USA & Carp & $\mathrm{n} / \mathrm{a}$ & $\mathrm{n} / \mathrm{a}$ & $32-920$ & $\mathrm{n} / \mathrm{a}$ & {$[5]$} \\
\hline USA & Carp; Walleye & $\mathrm{n} / \mathrm{a}$ & $\mathrm{n} / \mathrm{a}$ & $4900-8200$ & $\mathrm{n} / \mathrm{a}$ & {$[3]$} \\
\hline USA & Small mouth bass & $800-29,000$ & $\mathrm{n} / \mathrm{a}$ & $\mathrm{n} / \mathrm{a}$ & $\mathrm{n} / \mathrm{a}$ & [9] \\
\hline Taiwan & Fish & $2.85-1243$ & $\mathrm{n} / \mathrm{a}$ & $\mathrm{n} / \mathrm{a}$ & $\mathrm{n} / \mathrm{a}$ & {$[13]$} \\
\hline Germany & Coregonus sp. & $\mathrm{n} / \mathrm{a}$ & $\mathrm{n} / \mathrm{a}$ & $\mathrm{n} / \mathrm{a}$ & $40-60$ & {$[21]$} \\
\hline Australia & Fish & $6.4-115.4$ & $\mathrm{n} / \mathrm{a}$ & $\mathrm{n} / \mathrm{a}$ & $\mathrm{n} / \mathrm{a}$ & [25] \\
\hline Spain & Trout & $0.024-11.48$ & $\mathrm{n} / \mathrm{a}$ & $\mathrm{n} / \mathrm{a}$ & $\mathrm{n} / \mathrm{a}$ & [23] \\
\hline South Africa & Carp; Labeo umbratus & $11.58-18.68$ & $5.52-6.33$ & $32.57-47.18$ & $6.64-11.86$ & This study \\
\hline
\end{tabular}

n/a: not applicable. 
consistent with previous studies, which indicated that BDE47 and BDE99, in particular, bio-accumulate and biomagnify up the food chain [9] [13] [22] [23]. Another factor that might be important is debromination of the higher substituted congeners resulting in increasing concentration of lower substituted BDEs over time [24]. The reported concentration of BFRs, are slightly lower than the results reported by des Jardins Anderson \& MacRae [9], Peng et al. [13] and Losada et al. [25] but similar with concentrations reported by Lacorte et al. [23]. Some of the key activities along the river include flows from wastewater treatment works, stock farming, irrigation agricultural activities as well as the overall increase in human population around the sub-catchment area. These activities may be responsible for the observed levels of the analytes determined.

\section{Conclusion}

Using a simplified derivatization approach as described in this study, the presence and levels of APEs and BFRs in fish samples collected from the Vaal River in Gauteng, South Africa, were determined simultaneously. The large variation in the concentrations of APEs and BFRs found in the fish may be attributed to feeding habit of the fish and the exposure levels of contamination in the river. In comparison to other reported concentrations, our finding indicated a moderate contamination level for both types of compounds; however, owing to lack of specific regulations for APEs and BFRs in environmental samples in South Africa at present, further studies on determining the source of these pollutants in the environment are needed.

\section{Acknowledgements}

The authors are indebted to Rand Water for providing the technical environment and funding for this project which is part of Mr. Chokwe's doctoral degree and Tshwane University of Technology for support.

\section{References}

[1] Cathum, S. and Sabik, H. (2001) Simultaneous Determination of Alkylphenol Polyethoxylate Surfactants and Their Degradation Products in Water, Effluent and Mussel Using Gas-Chromatography-Mass Spectrometry. Chromatographia, 51, 400-405. http://dx.doi.org/10.1007/BF02490365

[2] de Wit, C.A. (2002) An Overview of Brominated Flame Retardants in the Environment. Chemosphere, 46, 583-624. http://dx.doi.org/10.1016/S0045-6535(01)00225-9

[3] Schmitz-Afonso, I., Loyo-Rosales, J.L., de la Paz Aviles, M., Rattner, B.A. and Rice, C.P. (2003) Determination of Alkylphenol and Alkylphenol Ethoxylates in Biota by Liquid Chromatography with Detection by Tandem Mass Spectrometry and Fluorescence Spectroscopy. Journal of Chromatography A, 1010, 25-35. http://dx.doi.org/10.1016/S0021-9673(03)00956-7

[4] Ying, G.-G., Williams, B. and Kookana, R. (2002) Environmental Fate of Alkylphenols and Alkylphenol Ethoxylates-A Review. Environmental International, 28, 215-226. http://dx.doi.org/10.1016/S0160-4120(02)00017-X

[5] Rice, C.P., Schmitz-Alfonso, I., Loyo-Rosales, J.E., Link, E., Thoma, R., Fay, L., Altfater, D. and Camp, M.J. (2003) Alkylphenol and Alkylphenol Ethoxylates in Carp, Water and Sediment from the Cuyahoga River, Ohio. Environmental Science Technology, 37, 3747-3754. http://dx.doi.org/10.1021/es0341050

[6] Bientinesi, M. and Petarca, L. (2009) Comparative Environmental Analysis of Waste Brominated Plastic Thermal Treatments. Waste Management, 29, 1095-1102. http://dx.doi.org/10.1016/j.wasman.2008.08.004

[7] Segev, O., Kushmaro, A. and Brenner, A. (2009) Environmental Impact of Flame Retardants (Persistence and Biodegradability). International Journal Environmental Research Public Health, 6, 478-491. http://dx.doi.org/10.3390/ijerph6020478

[8] Datta, S., Loyo-Rosales, J.E. and Rice, C.P. (2002) A Simple Method for the Determination of Trace Levels of Alkylphenolic Compounds in Fish Tissue Using Pressurized Fluid Extraction, Solid Phase Clean up and High Performance Liquid Chromatography Fluorescence Detection. Journal of Agricultural and Food Chemistry, 50, 1350-1354. http://dx.doi.org/10.1021/jf0111357

[9] Des Jardins Anderson, T. and MacRae, J.D. (2006) Polybrominated Diphenyl Ethers in Fish and Wastewater Samples from an Area of the Penobscot River in Central Maine. Chemosphere, 62, 1153-1160. http://dx.doi.org/10.1016/j.chemosphere.2005.06.034

[10] de Boer, J., Allchin, C.R., Law, R., Zegers, B.N. and Boon, J.P. (2001) Method for the Analysis of Polybrominated Diphenylethers in Sediments and Biota. Trends in Analytical Chemistry, 20, 591-599.

http://dx.doi.org/10.1016/S0165-9936(01)00097-8 
[11] Sabik, H., Gagné, F., Blaise, C., Marcogliese, D.J. and Jeannot, R. (2003) Occurrence of Alkylphenol Polyethoxylates in the St. Lawrence River and Their Bioconcentration by Mussels (Elliptio complanata). Chemosphere, 51, 349-356. http://dx.doi.org/10.1016/S0045-6535(02)00862-7

[12] Morris, S., Bersuder, P., Allchin, C.R., Zegers, B., Boon, J.P., Leonards, P.E.G. and de Boer, J. (2006) Determination of the Brominated Flame Retardant, Hexabromocyclododecane, in Sediments and Biota by Liquid Chromatography-Electrospray Ionization Mass Spectrometry. Trends in Analytical Chemistry, 25, 343-349. http://dx.doi.org/10.1016/j.trac.2005.11.006

[13] Peng, J.H., Huang, C.W., Weng, Y.M. and Yak, H.K. (2007) Determination of Polybrominated Diphenyl Ethers (PBDEs) in Fish Samples from Rivers and Estuaries in Taiwan. Chemosphere, 66, 1990-1997. http://dx.doi.org/10.1016/j.chemosphere.2006.07.094

[14] Sibali, L.L., Okonkwo, J.O. and McCrindle, R.I. (2008) Determination of Selected OCP Compounds from the Jukskei River Catchment Area in Gauteng, South Africa. Water SA, 34, 611-621.

[15] Sibali, L.L., Okonkwo, J.O. and McCrindle, R.I. (2010) Levels of Selected Alkylphenol Ethoxylates (APEs) in Water and Sediment Samples from Jukskei River Catchment Area in Gauteng, South Africa. Water SA, 36, 229-238.

[16] Daso, A.P., Fatoki, O.S. and Odendaal, J.P. (2011) Development of Analytical Procedures for the Simultaneous Determination of Tri- to Heptabrominated Diphenyl Ethers and Hexabrominated Biphenyl (BB153) in Sediment Samples. Water SA, 37, 331-338. http://dx.doi.org/10.4314/wsa.v37i3.68484

[17] Olukunle, O., Okonkwo, J., Kefeni, K. and Lupankwa, M. (2012) Concentrations of Polybrominated Diphenyl Ethers in Sediments from Jukskei River, Gauteng, South Africa. Bulletin of Environmental Contamination and Toxicology, 88, 461-466. http://dx.doi.org/10.1007/s00128-011-0481-y

[18] Polder, A., Bester, B., Skaare, J.U. and Bouman, H. (2008) Polybrominated Diphenyl Ethers and HBCD in Bird Eggs of South Africa. Chemosphere, 73, 148-154. http://dx.doi.org/10.1016/j.chemosphere.2008.03.021

[19] EPA (2000) Guidance for Assessing Chemical Contaminant Data for Use in Fish Advisories. Vol. 1, Fish Sampling and Analysis. U.S. Environmental Protection Agency, Office of Water, EPA-823-B-00-007, Washington DC.

[20] Chokwe, T.B., Okonkwo, J.O., Sibali, L.L. and Ncube, E.J. (2014) Improved Derivatization Protocol for Simultaneous Determination of Alkylphenol Ethoxylates and Brominated Flame Retardants Followed by Gas Chromatography-Mass Spectrometry. Water Science \& Technology, 69, 2389-2396. http://dx.doi.org/10.2166/wst.2014.144

[21] Hiebl, J. and Vetter, W. (2007) Detection of Hexabromocyclododecane and Its Metabolite Pentabromocyclododecene in Chicken Egg and Fish from the Official Food Control. Journal of Agricultural and Food Chemistry, 55, 3319-3324. http://dx.doi.org/10.1021/jf063428b

[22] McDonald, T.A. (2002) A Perspective on the Potential Health Risks of PBDEs. Chemosphere, 46, 745-755. http://dx.doi.org/10.1016/S0045-6535(01)00239-9

[23] Lacorte, S., Ikonomou, M.G. and Fischer, M. (2010) A Comprehensive Gas Chromatography Coupled to High Resolution Mass Spectrometry Based Methods for the Determination of Polybrominated Diphenyl Ethers and Their Hydroxylated and Methoxylated Metabolites in Environmental Samples. Journal of Chromatography A, 1217, 337-347. http://dx.doi.org/10.1016/j.chroma.2009.11.024

[24] Stapleton, H.M., Alaee, M., Letcher, R.J. and Baker, J.E. (2004) Debromination of the Flame Retardant Decabromodiphenyl Ether by Juveline Carp (Cyprinus carpio) Following Dietary Exposure. Environmental Science and Technology, 38, 112-119. http://dx.doi.org/10.1021/es034746j

[25] Losada, S., Roach, A., Roosens, L., Santos, F.J., Galceran, M.T., Vetter, W., Neels, H. and Covaci, A. (2009) Biomagnification of Anthropogenic and Naturally-Produced Organobrominated Compounds in a Marine Food Web from Sydney Harbor, Australia. Environment International, 35, 1142-1149. http://dx.doi.org/10.1016/j.envint.2009.07.008 